\title{
Casein Kinase $1 \alpha$ as a Regulator of Wnt-Driven Cancer
}

\author{
Chen Shen ${ }^{1,2}{ }^{2}$ Anmada Nayak ${ }^{1}$, Ricardo A. Melendez ${ }^{1}$, Daniel T. Wynn ${ }^{1}$, Joshua Jackson ${ }^{1}{ }^{(D)}$ \\ Ethan Lee ${ }^{3}{ }^{\circ}$, Yashi Ahmed ${ }^{4}$ and David J. Robbins ${ }^{1,5, *}$ \\ 1 Molecular Oncology Program, The DeWitt Daughtry Family Department of Surgery, Miller School of \\ Medicine, University of Miami, Miami, FL 33136, USA; cxs899@miami.edu (C.S.); \\ axn567@med.miami.edu (A.N.); r.melendez@umiami.edu (R.A.M.); DWynn@med.miami.edu (D.T.W.); \\ jjackson@miami.edu (J.J.) \\ 2 The Sheila and David Fuente Graduate Program in Cancer Biology, Miller School of Medicine, University of \\ Miami, Miami, FL 33136, USA \\ 3 Department of Cell and Developmental Biology, Vanderbilt University, Nashville, TN 37232, USA; \\ ethan.lee@vanderbilt.edu \\ 4 Department of Molecular and Systems Biology and the Norris Cotton Cancer Center, Geisel School of \\ Medicine, Dartmouth College, Hanover, NH 03755, USA; yashi.ahmed@dartmouth.edu \\ 5 Sylvester Comprehensive Cancer Center, Miller School of Medicine, University of Miami, \\ Miami, FL 33136, USA \\ * Correspondence: drobbins@med.miami.edu; Tel.: +1-305-243-5717
}

Received: 24 July 2020; Accepted: 14 August 2020; Published: 18 August 2020

\begin{abstract}
Wnt signaling regulates numerous cellular processes during embryonic development and adult tissue homeostasis. Underscoring this physiological importance, deregulation of the Wnt signaling pathway is associated with many disease states, including cancer. Here, we review pivotal regulatory events in the Wnt signaling pathway that drive cancer growth. We then discuss the roles of the established negative Wnt regulator, casein kinase $1 \alpha(\mathrm{CK} 1 \alpha)$, in Wnt signaling. Although the study of CK $1 \alpha$ has been ongoing for several decades, the bulk of such research has focused on how it phosphorylates and regulates its various substrates. We focus here on what is known about the mechanisms controlling $\mathrm{CK} 1 \alpha$, including its putative regulatory proteins and alternative splicing variants. Finally, we describe the discovery and validation of a family of pharmacological CK1 $\alpha$ activators capable of inhibiting Wnt pathway activity. One of the important advantages of CK1 $\alpha$ activators, relative to other classes of Wnt inhibitors, is their reduced on-target toxicity, overcoming one of the major impediments to developing a clinically relevant Wnt inhibitor. Therefore, we also discuss mechanisms that regulate CK1 $\alpha$ steady-state homeostasis, which may contribute to the deregulation of Wnt pathway activity in cancer and underlie the enhanced therapeutic index of CK1 $\alpha$ activators.
\end{abstract}

Keywords: Wnt; cancer; targeted therapies; $\mathrm{CK} 1 \alpha$; kinase agonists; review

\section{Introduction}

The evolutionarily conserved Wnt signaling cascade has been extensively studied for over three decades and has been shown to regulate numerous cellular events during development and adult tissue homeostasis, as well as in disease when deregulated [1,2]. The term 'Wnt' was first coined in 1991 from a combination of wingless, the gene that patterns the development of many tissues in Drosophila melanogaster, including the wing, and its mouse ortholog Int-1, the proto-oncogene that regulates mammary tumorigenesis in mice [3]. Wnt ligands are a family of secreted glycoproteins that trigger a unique signal transduction network $[4,5]$. Wnt proteins undergo palmitoylation by the 
membrane-bound O-acyltransferase porcupine (PORCN) in the endoplasmic reticulum (ER) [6-8]. This modification promotes Wnt export from the ER and subsequently out of the cell and facilitates its activation and binding to the membrane receptor frizzled (Fzd) [6-10]. Two distinct arms of the Wnt signaling network have been identified, defined by their dependence on $\beta$-catenin: canonical $W n t / \beta$-catenin signaling and non-canonical Wnt signaling. In this review, we focus on the canonical Wnt signaling pathway, discussing the role of its various critical components in cancer, with a focus on the established negative regulator of Wnt signaling, casein kinase $1 \alpha(\mathrm{CK} 1 \alpha)$.

\section{Wnt Signaling}

\subsection{At the Membrane}

In the absence of Wnt ligands, the transmembrane Wnt receptors Fzd and low-density lipoprotein receptor-related protein 5/6 (LRP5/6) undergo lysosomal degradation, mediated by the E3 ubiquitin ligase zinc- and ring-finger protein 3 (ZNRF3) and its paralog ring-finger protein 43 (RNF43), to maintain low-level Wnt signal transduction (Figure 1) [11,12]. Upon binding of Wnt ligands, Fzd and LRP5/6 oligomerize and recruit disheveled (Dvl) to form the Wnt "signalosome" and initiate signal transduction [13-18]. All Wnt ligands activate Dvl, which can stimulate both canonical and non-canonical Wnt signaling, albeit through distinct domains [19]. Additionally, in the presence of Wnt ligands, the R-spondin family of secreted ligands (RSPOs) bind to either leucine-rich repeat-containing G-protein coupled receptors 4/5/6 (LGR4/5/6) or heparan sulfate proteoglycans (HSPG) to attenuate Fzd degradation by ZNRF3/RNF43, thereby increasing the strength of Wnt signaling (Figure 1) [11,12,20-29].
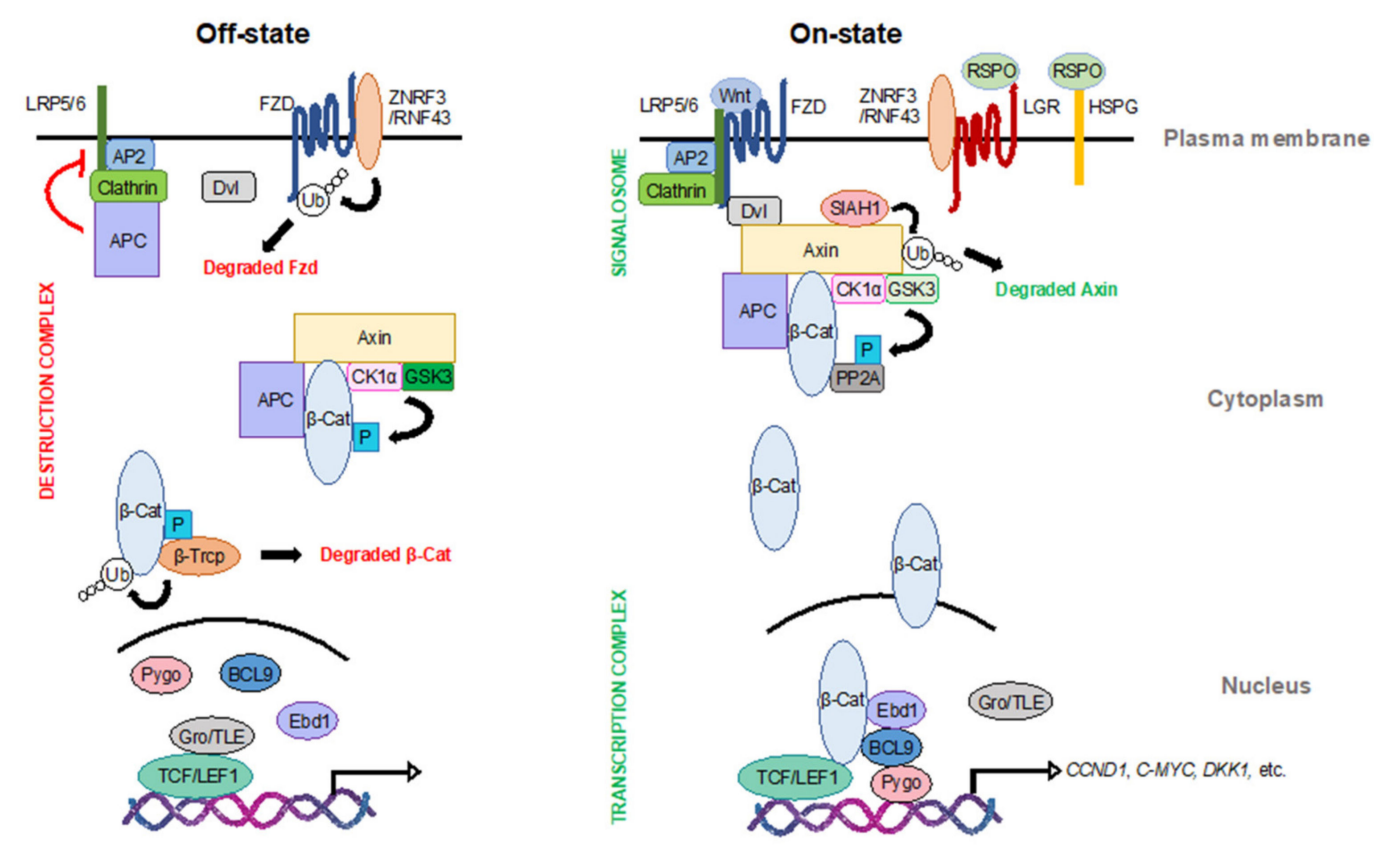

Figure 1. The canonical Wnt signaling pathway. In the Wnt off-state (left), $\beta$-catenin, the pivotal transcription coactivator of the Wnt pathway, is degraded by the destruction complex in the cytoplasm. Other Wnt effectors, such as frizzled (Fzd) at the membrane and T cell factor (TCF)/lymphoid enhancer-binding factor 1 (LEF1) transcription factors in the nucleus, are also inhibited to maintain low Wnt activity. In the Wnt on-state (right), Wnt ligands trigger the formation of the signalosome to promote Wnt signal transduction. 
The function of the destruction complex is inhibited, leading to the stabilization of $\beta$-catenin. $\beta$-catenin then translocates into the nucleus and binds to TCF/LEF1 to form a transcription complex along with other cofactors to initiate Wnt target transcription. LRP5/6: low-density lipoprotein receptor-related protein 5/6; ZNRF3: E3 ubiquitin ligase zinc- and ring-finger protein 3; RNF43: ring-finger protein 43; Dvl: disheveled; AP2: adapter protein 2; APC: adenomatous polyposis coli; CK1 $\alpha$ : casein kinase $1 \alpha$; GSK3: glycogen synthase kinase 3; Gro/TLE: groucho/transducin-like enhancer of split proteins; Pygo: pygopus; BCL9: B cell lymphoma 9 protein; Ebd1: earthbound 1; RSPO: R-spondin family of secreted ligands; LGR: leucine-rich repeat-containing G-protein coupled receptors; HSPG: heparan sulfate proteoglycans; SIAH1: siah E3 ubiquitin ligase 1; PP2A: protein phosphatase 2A.

\subsection{In the Cytoplasm}

In the absence of Wnt, a cytosolic multi-protein complex consisting of the scaffold protein axin, adenomatous polyposis coli (APC), and two protein kinases-casein kinase $1 \alpha(\mathrm{CK} 1 \alpha)$ and glycogen synthase kinase 3 (GSK3) - regulates the phosphorylation and subsequent degradation of the transcriptional regulator $\beta$-catenin (Figure 1) [30-33]. Axin contains multiple functional domains that interact with $\mathrm{CK} 1 \alpha$, GSK3, and $\beta$-catenin and serves to nucleate the formation and stability of this so-called destruction complex. This complex mediates the phosphorylation of $\beta$-catenin by CK $1 \alpha$ at Ser 45, which primes it for subsequent phosphorylation by GSK3 at Ser 33, Ser 37, and Thr 41 [30,34]. APC also facilitates the phosphorylation of $\beta$-catenin in an axin-dependent manner [35-37]. Phosphorylated $\beta$-catenin is then ubiquitinated by the F-box E3 ubiquitin ligase $\beta$-Trcp and subsequently degraded by the proteasome $[38,39]$. Besides its well-established role in mediating $\beta$-catenin's phosphorylation, APC also attenuates Wnt signaling via a second distinct mechanism [40,41]. In this second role, APC binds to clathrin and adaptor protein 2 (AP2), to prevent LRP6 endocytosis and suppress signalosome formation in the absence of Wnt ligands [40,41].

In response to Wnt ligands, components of the destruction complex are recruited to the plasma membrane, where axin interacts with LRP5/6 to promote signalosome formation and subsequent activation $[17,42,43]$. In this Wnt on-state, the $\beta$-catenin destruction complex is inhibited, resulting in the stabilization and nuclear accumulation of $\beta$-catenin (Figure 1) [44,45]. During this process, GSK3 kinase activity is the rate-limiting factor, controlling $\beta$-catenin destruction $[46,47]$. In addition, Wnt signaling can attenuate the formation of the destruction complex through the degradation of axin, which is mediated by the siah E3 ubiquitin ligase 1 (SIAH1) [43,48-50].

\subsection{In the Nucleus}

In the absence of nuclear $\beta$-catenin, the groucho/transducin-like enhancer of split proteins (Gro/TLE) bind to the T cell factor (TCF)/lymphoid enhancer-binding factor 1 (LEF1) family of transcription factors to repress the Wnt transcriptional program (Figure 1) [51]. Upon Wnt activation, Gro/TLE proteins undergo ubiquitination and degradation, allowing $\beta$-catenin to associate with TCF/LEF1 and initiate the Wnt transcriptional program [51-53]. This process is modulated by a variety of other co-factors, such as B cell lymphoma 9 protein (BCL9), pygopus (Pygo), and earthbound1 (Ebd1)/jerky $[54,55]$. Together with these transcriptional co-factors, $\beta$-catenin initiates the transcription of a series of Wnt target genes, such as CYCLIN D1, C-MYC, and DICKKOPF1, which play important roles in the regulation of cell proliferation, survival, and differentiation [56-58].

\section{Wnt Signaling and Cancer}

The relationship between Wnt signaling and cancer was discovered in the 1980s when the proto-oncogene Int1 (Wnt1) was shown to induce mammary adenocarcinoma in mice [59,60]. A large number of studies have now validated the important role Wnt signaling plays in the onset and progression of a large variety of cancers, largely due to mutations or altered expression of a subset of Wnt signaling components [61,62]. One of the most frequently mutated Wnt signaling components in cancer is $A P C$. APC is considered the gatekeeper gene of colorectal carcinoma (CRC), as the vast majority of CRCs result from its mutation [61]. Initially, germline mutations of APC were 
discovered to underlie familial adenomatous polyposis (FAP), an inherited precancerous condition that ultimately gives rise to CRC [63-65]. Later, somatic APC mutations were also shown to play an important role in the development of sporadic CRC $[66,67]$. APC loss-of-function mutations result in increased $\beta$-catenin/TCF4-driven transcription, linking the initiation of CRCs to aberrant Wnt pathway activation $[31,68,69]$. Besides CRC, APC mutation is also associated with the genesis of other types of cancers, such as gastric cancer and hepatoblastoma [70-73]. Other Wnt signaling components are also frequently mutated in cancer, including the genes encoding axin1 [74], $\beta$-catenin [75-78], TCF4 [79,80], and RNF43/ZNRF3 [81-83].

Deregulation of the expression of Wnt signaling components is also associated with oncogenesis, both through decreased expression of negative regulators and increased expression of positive regulators [84-87]. For example, microRNA-135 decreases APC expression via the three prime untranslated region ( $3^{\prime}$-UTR) and leads to Wnt pathway activation in colorectal cancers [88]. Increased protein abundance of Wnt signaling effectors, such as $\beta$-catenin and TCF4, due to the deregulation of protein translation, has also been observed in various cancers [89-91]. Additionally, the deregulation of the Wnt signaling components' post-translational modification can also drive tumorigenesis [92-94]. For example, in colorectal cancer, TLE3 is ubiquitinated and degraded by RNF6 to facilitate the formation of $\beta$-catenin/TCF transcription complex, thereby activating Wnt signaling [94].

Given that constitutive Wnt signaling drives the growth of a large number of cancers, the development of Wnt inhibitors has been a focus of the field for several decades. However, no Wnt inhibitor is currently approved by the U.S. Food and Drug Administration (FDA) for use in the clinic. The major challenge to developing clinically relevant Wnt inhibitors is to overcome the dose-limiting on-target toxicity of such inhibitors in attenuating homeostatic Wnt signaling, primarily in the intestine and bone [2]. We have recently identified several small-molecule CK1 $\alpha$ activators that constitute a novel class of Wnt inhibitors capable of attenuating Wnt-driven tumorigenesis without exhibiting significant on-target toxicity [95-101]. These findings highlight $\mathrm{CK} 1 \alpha$ as a promising therapeutic target in Wnt-driven cancers.

\section{CK1 $\alpha$}

\subsection{CK1 Family Members}

Casein kinases (CKs) were discovered in the 1970s as cytoplasmic protein kinases purified from rat liver, which were able to phosphorylate casein on Ser and Thr residues [102]. Subsequently, multiple CKs were identified and divided into two major groups, CK1 and CK2, based on their biochemical properties [103]. Besides CK1 $\alpha$, the CK1 family of genes encodes CK1 $\beta, \delta, \varepsilon, \gamma 1, \gamma 2$, and $\gamma 3$ [104]. CK1 family members are broadly expressed throughout development and in numerous adult tissues in humans, except CK1 $\beta$, which is found only in cattle [104]. The primary sequence alignment of CK1 family members highlights a highly conserved Ser/Thr protein kinase domain flanked by distinct amino-terminal (N-term) and carboxyl-terminal (C-term) extensions. Consistent with their homologous protein kinase domain, CK1 family members exhibit similar substrate specificity in vitro. The consensus phosphorylation motif recognized by CK1 was originally identified as a phosphorylated $\mathrm{Ser} / \mathrm{Thr}$ residue (pSer/Thr) or an acidic group of amino acids upstream of two to four residues, followed by a Ser/Thr phosphor-acceptor [105]. CK1 is also able to phosphorylate substrates at non-consensus sequences [106,107]. For example, CK1 $\alpha$ phosphorylates $\beta$-catenin at the first serine residue in a novel serine-leucine-serine (SLS) motif upstream of an acidic cluster of six amino acids [107].

\subsection{CK1 in Wnt Signaling}

Despite their substrate similarity in vitro, the substrates of CK1 family members likely vary in vivo. Multiple $\mathrm{CK} 1$ family members $(\mathrm{CK} 1 \alpha, \delta, \varepsilon, \gamma 1)$ regulate Wnt signaling, and this regulation occurs via the phosphorylation of distinct substrates [108]. CK1 $\delta$ and CK1 $\varepsilon$ share the highest primary sequence identity and can play a redundant function, such as the phosphorylation and positive 
regulation of Dvl [109]. CK1 1 and $C K 1 \gamma 1$ also play positive roles in Wnt signaling, respectively, by phosphorylating TCF3 to enhance its activity [110] or phosphorylating LRP5/6 to enhance signal transduction [111]. In contrast to other CK1 family members, CK1 $\alpha$ plays a negative role in Wnt pathway regulation [112,113]. In addition to its well-established role in the cytosolic $\beta$-catenin destruction complex, CK1 $\alpha$ also regulates the steady-state levels of nuclear Pygo to attenuate $\beta$-catenin/TCF-driven Wnt pathway activity [95].

\subsection{CK1 $\alpha$ Splice Variants}

The CK1 $\alpha$ gene, CSNK1A1, undergoes alternative splicing to produce four splice variants [114-116]. These splice variants are distinguished by the absence or presence of a long insert (L) of 28 amino acids in the protein kinase domain or a short insert (S) of 12 amino acids near the C-terminus. In human, the four CK1 $\alpha$ splice variants include CK1 $\alpha$ with both $\mathrm{L}$ and $\mathrm{S}$ inserts (CK1 $\alpha \mathrm{LS}), \mathrm{CK} 1 \alpha$ with only an S insert $(\mathrm{CK} 1 \alpha \mathrm{S}), \mathrm{CK} 1 \alpha$ with no insert $(\mathrm{CK} 1 \alpha \mathrm{NI})$, and $\mathrm{CK} 1 \alpha \mathrm{LS}$ with a truncated $\mathrm{N}$-term $(\mathrm{CK} 1 \alpha \mathrm{SN})$ (Figure 2). The L insert contains a nuclear localization signal (NLS), leading to the preferential nuclear enrichment of CK1 $\alpha$ splice variants with this insert [116,117]. CK1 $\alpha$ splice variants also exhibit other distinct biological properties, including kinetic characteristics, response to small-molecule modulators, thermal stability, and autophosphorylation [114-116,118]. In cells, ectopic expression of the various $\mathrm{CK} 1 \alpha$ splice variants leads to varying phosphorylation of cellular $\beta$-catenin on Ser45, suggesting that CK1 $\alpha$ splice variants might also affect Wnt pathway activity differentially [119].

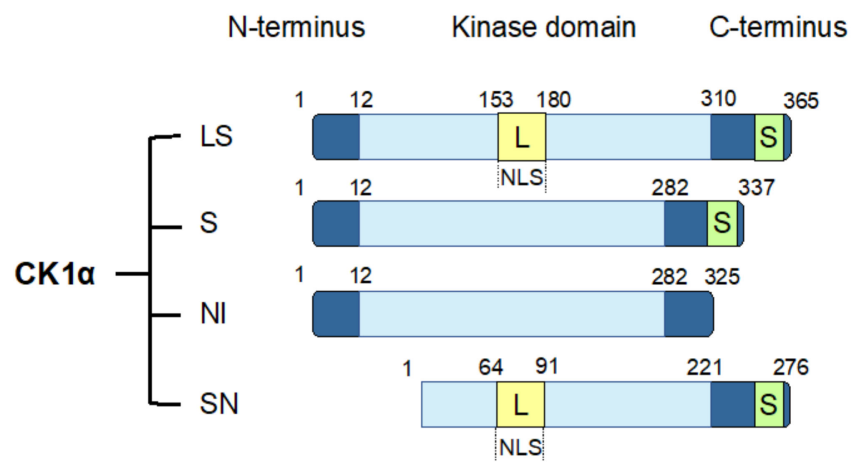

Figure 2. CK1 $\alpha$ splice variants. Human $\mathrm{CK} 1 \alpha$ undergoes alternative splicing to produce four splice variants, as shown. These $\mathrm{CK} 1 \alpha$ splice variants are characterized by the insertion of two polypeptide sequences: a long insertion (L) that contains a nuclear localization signal (NLS) into the protein kinase domain, and a short insertion (S) close to the C-terminus. LS: CK1 $\alpha$ with both L and S inserts; S: CK1 $\alpha$ with only an S insert; NI: CK1 $\alpha$ with no insert; SN: CK1 $\alpha$ LS with an N-terminal truncation.

\subsection{Regulation of CK1 $\alpha$}

Although the mechanisms by which CK $1 \alpha$ regulates cellular processes, including Wnt signaling, are well established, the regulation of $\mathrm{CK} 1 \alpha$ itself is poorly understood and is thus an active area of investigation. Recently, multiple proteins have been described that regulate the intracellular localization of CK1 $\alpha$ (Figure 3) [120,121]. For example, in prostate cancers, glioma pathogenesis-related protein 1 (GLIPR1) mediates the translocation of CK1 $\alpha$ to the nucleus, leading to the phosphorylation and degradation of C-Myc and inhibition of Wnt activity [120]. The protein levels of CK1 $\alpha$ can also be regulated: family with sequence similarity $83 \mathrm{G}$ protein (FAM83G) (also known as protein associated with SMAD1 (PAWS1)) interacts with CK1 $\alpha$ in the $\beta$-catenin destruction complex and stabilizes CK1 $\alpha$ protein, subsequently regulating Wnt signal transduction (Figure 3) [122]. In addition, CK1 $\alpha$ gene expression and protein abundance are decreased in many Wnt-driven cancers $[78,85,97]$. 


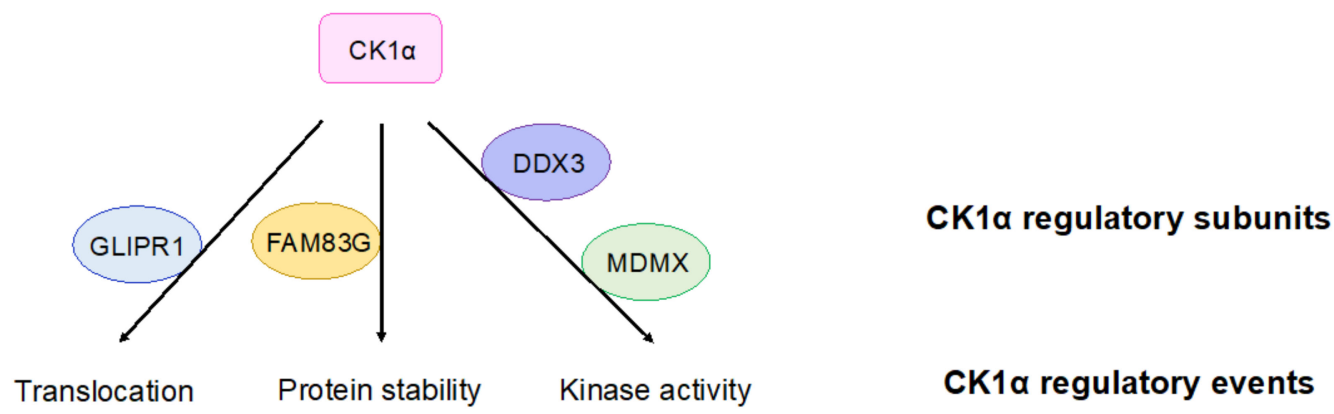

Figure 3. $\mathrm{CK} 1 \alpha$ regulatory subunits. Proteins that have been reported to regulate $\mathrm{CK} 1 \alpha$ are shown. These proteins bind to $\mathrm{CK} 1 \alpha$ and lead to indicated regulatory outcomes of CK1 $\alpha$. GLIPR1: glioma pathogenesis-related protein 1; FAM83G: family with sequence similarity 83G protein; DDX3: DEAD-box RNA helicase 3; MDMX: murine double minute X.

The protein kinase activity of CK1 $\alpha$ can be regulated by the presence of DEAD-box RNA helicase 3 (DDX3) in the basal state-upon loss of DDX3, CK1 $\alpha$ kinase activity is decreased in cells (Figure 3) [123]. However, whether DDX3 directly regulates $\mathrm{CK} 1 \alpha$ is unclear. The P53 inhibitor protein murine double minute $\mathrm{X}$ (MDMX) can also inhibit CK1 $\alpha$ 's kinase activity upon their binding, resulting in the activation of Wnt signaling (Figure 3) [124]. This result suggests that MDMX, which binds to CK1 $\alpha$ in a stoichiometric fashion, functions as a regulatory subunit for CK $1 \alpha$ in Wnt signaling. CK $1 \alpha$ is also capable of autophosphorylation, which limits its own kinase activity in vitro [118]. Although the autophosphorylation of $\mathrm{CK} 1 \delta / \varepsilon$ can be reversed by Wnt signaling, there is currently no evidence showing that $\mathrm{CK} 1 \alpha$ autophosphorylation can be regulated by Wnt signaling [125].

\section{CK1 $\alpha$ Activators}

\subsection{Pyroinium}

Based on its important negative role in Wnt signaling, pharmacological activation of CK1 $\alpha$ should attenuate Wnt activity. The FDA-approved anthelmintic drug pyrvinium has been the first-in-class small-molecule CK1 $\alpha$ activator (Figure $4 \mathrm{~A}$ ), having been identified as a Wnt pathway inhibitor in a large-scale screen of FDA-approved drugs in Xenopus laevis embryo extracts [95]. Importantly, pyrvinium has no observable effect on other pathways examined. CK1 $\alpha$ is identified as the target of pyrvinium using a candidate approach and then validated in multiple ways. Although it is shown to bind to multiple CK1 family members, pyrvinium only activates the protein kinase activity of CK1 $\alpha$, consistent with pyrvinium acting as a pharmacological CK1 $\alpha$ activator $[95,119]$. Pyrvinium, but not its structural analog VU-WS211 (Figure 4A), activates CK1 $\alpha$ by increasing its $V_{\max }$, without changing its $K_{m}$ for its substrate [119]. These results suggest that pyrvinium activation of CK1 $\alpha$ increases the catalytic activity of $\mathrm{CK} 1 \alpha$ without affecting substrate binding, potentially through an allosteric mechanism (Figure 4B) [95,119]. Interestingly, when comparing the activity of cells transfected with plasmids expressing the four $\mathrm{CK} 1 \alpha$ splice variants, pyrvinium is only able to enhance the activity of those variants lacking the $\mathrm{L}$ insert and activated $\mathrm{CK} 1 \alpha \mathrm{S}$ the most [119]. Given the location of the $\mathrm{L}$ insert within CK1 $\alpha^{\prime}$ s protein kinase domain, which is close to its activation loop (AA 156-190) [126], this result suggests that the $L$ insert may interfere with the binding of pyrvinium to the active site of CK1 $\alpha$. 
A
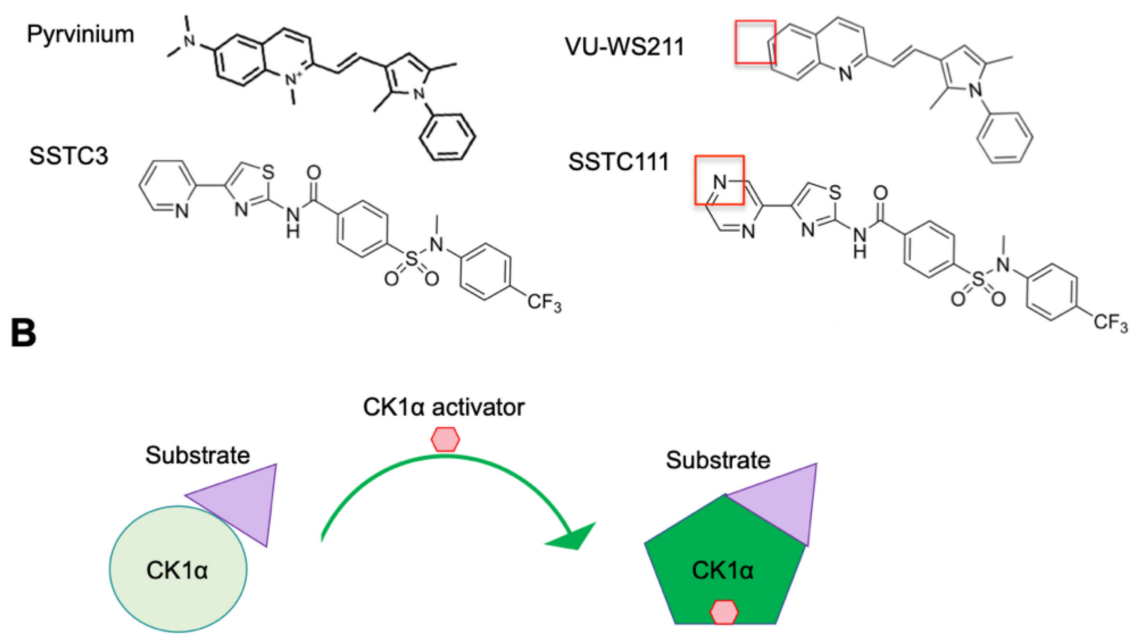

C

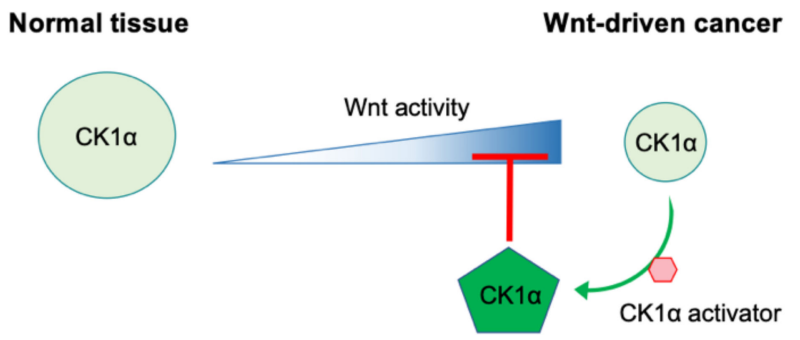

Figure 4. CK1 $\alpha$ activators. (A) The structures of two chemically distinct CK1 $\alpha$ activators-pyrvinium and SSTC3 - and their inactive analogs-VU-WS211 and SSTC111—respectively, are shown. The red boxes highlight key structures needed for maximal efficacy. (B) A model, highlighting how CK1 $\alpha$ activators function to increase the catalytic efficiency of CK1 $\alpha$. (C) A model of the mechanism underlying the differential therapeutic index of CK1 $\alpha$ activators in normal tissue and Wnt-driven cancer.

Consistent with the pivotal role of $\mathrm{CK} 1 \alpha$ in Wnt signaling, pyrvinium attenuates the growth of Wnt-dependent CRC cell lines in a CK1 $\alpha$-dependent manner [95,96]. Pyrvinium also exhibits efficacy against a number of other Wnt-driven cancer cell lines, including those derived from breast cancer and hepatocellular carcinoma [98-101,127]. Pyrvinium inhibits Wnt pathway activity by reducing $\beta$-catenin levels in the cytoplasm and by increasing the degradation of the $\beta$-catenin/TCF coactivator Pygo in the nucleus [95]. Consistent with Pygo being a relevant nuclear target of CK1 $\alpha$ in Wnt signaling, pyrvinium is able to attenuate the growth of a CRC cell line, harboring a constitutively active $\beta$-catenin oncogenic mutant that lacks the CK1 $\alpha$ phospho-acceptor Ser [95,96]. Despite its potent Wnt-inhibiting effect ex vivo, the subsequent evaluation of pyrvinium's efficacy against the growth of Wnt-driven cancers in vivo has been limited, as pyrvinium has low bioavailability outside of the intestinal tract [128]. However, pyrvinium has been evaluated in a Wnt-dependent FAP-induced colorectal adenoma mouse model, in which it significantly decreases the formation of adenomatous polyps in an on-target manner [96]. Based on this work, pyrvinium has been designated by the FDA as an orphan drug for the treatment of FAP.

\subsection{SSTC Compounds}

A number of potent, chemically novel CK1 $\alpha$ activators (SSTC3 and SSTC104- see Figure 4), which have significantly improved bioavailability by comparison with pyrvinium, have been described [97,127]. These second-generation CK1 $\alpha$ activators bind to CK1 $\alpha$ in a manner that is competitive to pyrvinium, suggesting that they bind to a similar site on CK1 $\alpha$ [97]. They also attenuate 
Wnt activity in a manner that is dependent on CK1 $\alpha$. SSTC3, but not its structural analog SSTC111 (Figure 4A), inhibits the growth of Wnt-driven CRC cell lines and patient-derived CRC organoids ex vivo [97]. Consistent with its improved bioavailability, SSTC3 remains in plasma for $24 \mathrm{~h}$ after intraperitoneal injection in mice and is able to penetrate the blood-brain barrier [97,129]. Furthermore, SSTC3 significantly inhibits the growth of primary and metastatic tumors that develop from patient CRCs or a Wnt-driven CRC cell line implanted in mice [97]. Importantly, when used at a dose that is efficacious against CRC growth, SSTC3 exhibits no significant toxicity in mice. Specifically, the structure of normal intestinal tissue, which is one of the sites primarily impeded from on-target toxicity of most Wnt inhibitors, is not disrupted by SSTC 3 treatment. It has been proposed that the greater therapeutic index of SSTC 3 compared to other Wnt inhibitors is the result of the decreased abundance of CK1 $\alpha$ protein in CRC tissue versus normal intestinal tissue (Figure 4C). Thus, these reduced levels of CK1 $\alpha$ protein sensitize CRC cells to the enhanced activation of CK1 $\alpha$ in response to SSTC3 [97].

\section{Conclusions}

Although remarkable effort has been made in the identification and development of Wnt pathway inhibitors, the on-target toxicity of these drugs, including the disruption of bone and intestine tissues, has limited their clinical utility. However, the use of additional drugs that ameliorate these on-target toxicities has extended the potential of currently available Wnt-inhibiting drugs [130-132]. For example, a recent phase I trial result has shown that the co-administration of the PORCN inhibitor ETC-159 along with bone protective treatment in patients harboring solid tumors is safe [132]. We have discussed here that CK $1 \alpha$ activators show significant efficacy in treating Wnt-driven cancers, without exhibiting on-target toxicity in normal tissue homeostasis at therapeutic doses. Thus, these SSTC compounds have the potential to effectively target Wnt-driven cancers in the clinic, with minimal on-target toxicity.

As a ubiquitous protein kinase, CK1 $\alpha$ plays a role in many other cellular processes in addition to Wnt signaling [133]. For example, CK1 $\alpha$ is also an important regulator of Ras and Hedgehog pathways, which are two other major signaling pathways regulating numerous disease states [133]. Thus, the therapeutic use of $\mathrm{CK} 1 \alpha$ activators could be extended to other diseases in addition to Wnt-driven cancers. Indeed, it was previously demonstrated that pyrvinium and SSTC 3 could also inhibit the growth of Sonic Hedgehog-driven (Shh-driven) medulloblastoma [129,134]. Even though CK1 $\alpha$ can regulate both Shh and Wnt pathways, both CK1 $\alpha$ activators attenuate Shh activity without affecting Wnt signaling in these medulloblastoma models $[129,134]$. This suggests that the primary function of these drugs is not limited to Wnt inhibition and is likely context-dependent. However, it still remains possible that $\mathrm{CK} 1 \alpha$ activators can simultaneously regulate multiple cellular processes in contexts other than what has been discussed in this review.

In addition to Wnt- and Shh-driven cancers, CK1 $\alpha$ activators have also shown the ability to treat other diseases, such as RAS-driven cancer and Wnt-driven ischemic injury $[135,136]$. Thus, it becomes quite important to study the mechanisms that regulate CK1 $\alpha$. The known downstream effects of $\mathrm{CK} 1 \alpha$ regulation, e.g., CK1 $\alpha$ translocation, gene expression, protein abundance, and kinase activity, may guide the direction of future $\mathrm{CK} 1 \alpha$ studies. In addition, $\mathrm{CK} 1 \alpha$ activators may function by mimicking certain cellular components that can control CK1 $\alpha$ activity, suggesting CK1 $\alpha$ activators can serve as important tools to identify potential CK1 $1 \alpha$ regulatory machinery. Taken together, the significant cellular roles of $\mathrm{CK} 1 \alpha$, along with the promising therapeutic effects of $\mathrm{CK} 1 \alpha$ activators in various diseases, have highlighted the importance of understanding the regulation of $\mathrm{CK} 1 \alpha$.

Author Contributions: C.S. and D.J.R. conceived the outline. C.S., E.L., Y.A., and D.J.R. wrote the manuscript. A.N., R.A.M., J.J., and D.T.W. contributed to sections of the manuscript. C.S., A.N., R.A.M., D.T.W., E.L., Y.A., and D.J.R. critically revised the manuscript. All authors have read and agreed to the published version of the manuscript.

Funding: This work is supported by NIH grants: R01CA219189 and R01NS110591 to D.J.R., R35GM122516 to E.L., R01GM121421, R01GM122222, and R35GM136233 to Y.A., and R01CA244188 to D.J.R., E.L., and Y.A. This work was also supported by the National Cancer Institute of the NIH under Award Number P30CA240139. The content is solely the responsibility of the authors and does not necessarily represent the official views of the NIH. 
Acknowledgments: We thank the other members of the Robbins, Ahmed, and Lee laboratories for their comments and ideas regarding this review.

Conflicts of Interest: D.J.R. and E.L. are founders of StemSynergy Therapeutics Inc., a company commercializing small-molecule cell signaling inhibitors, including those targeting Wnt signaling. Both founders participated in the writing of the manuscript. D.J.R. participated in conceiving the outline, and the decision to publish this review.

\section{References}

1. Clevers, H. Wnt/beta-catenin signaling in development and disease. Cell 2006, 127, 469-480. [CrossRef] [PubMed]

2. Steinhart, Z.; Angers, S. Wnt signaling in development and tissue homeostasis. Development $2018,145$. [CrossRef] [PubMed]

3. Nusse, R.; Brown, A.; Papkoff, J.; Scambler, P.; Shackleford, G.; McMahon, A.; Moon, R.; Varmus, H. A new nomenclature for int-1 and related genes: The Wnt gene family. Cell 1991, 64, 231. [CrossRef]

4. Mikels, A.J.; Nusse, R. Wnts as ligands: Processing, secretion and reception. Oncogene 2006, 25, 7461-7468. [CrossRef] [PubMed]

5. Willert, K.; Nusse, R. Wnt proteins. Cold Spring Harb. Perspect. Biol. 2012, 4, a007864. [CrossRef]

6. Zhai, L.; Chaturvedi, D.; Cumberledge, S. Drosophila wnt-1 undergoes a hydrophobic modification and is targeted to lipid rafts, a process that requires porcupine. J. Biol. Chem. 2004, 279, 33220-33227. [CrossRef]

7. Van den Heuvel, M.; Harryman-Samos, C.; Klingensmith, J.; Perrimon, N.; Nusse, R. Mutations in the segment polarity genes wingless and porcupine impair secretion of the wingless protein. EMBO J. 1993, 12, 5293-5302. [CrossRef]

8. Kadowaki, T.; Wilder, E.; Klingensmith, J.; Zachary, K.; Perrimon, N. The segment polarity gene porcupine encodes a putative multitransmembrane protein involved in Wingless processing. Genes Dev. 1996, 10, 3116-3128. [CrossRef]

9. Hofmann, K. A superfamily of membrane-bound O-acyltransferases with implications for wnt signaling. Trends Biochem. Sci. 2000, 25, 111-112. [CrossRef]

10. Willert, K.; Brown, J.D.; Danenberg, E.; Duncan, A.W.; Weissman, I.L.; Reya, T.; Yates, J.R., 3rd; Nusse, R. Wnt proteins are lipid-modified and can act as stem cell growth factors. Nature 2003, 423, 448-452. [CrossRef]

11. Hao, H.X.; Xie, Y.; Zhang, Y.; Charlat, O.; Oster, E.; Avello, M.; Lei, H.; Mickanin, C.; Liu, D.; Ruffner, H.; et al. ZNRF3 promotes Wnt receptor turnover in an R-spondin-sensitive manner. Nature 2012, 485, 195-200. [CrossRef] [PubMed]

12. De Lau, W.; Peng, W.C.; Gros, P.; Clevers, H. The R-spondin/Lgr5/Rnf43 module: Regulator of Wnt signal strength. Genes Dev. 2014, 28, 305-316. [CrossRef] [PubMed]

13. Bhanot, P.; Brink, M.; Samos, C.H.; Hsieh, J.C.; Wang, Y.; Macke, J.P.; Andrew, D.; Nathans, J.; Nusse, R. A new member of the frizzled family from Drosophila functions as a Wingless receptor. Nature 1996, 382, 225-230. [CrossRef]

14. Tamai, K.; Semenov, M.; Kato, Y.; Spokony, R.; Liu, C.; Katsuyama, Y.; Hess, F.; Saint-Jeannet, J.P.; He, X. LDL-receptor-related proteins in Wnt signal transduction. Nature 2000, 407, 530-535. [CrossRef] [PubMed]

15. Umbhauer, M.; Djiane, A.; Goisset, C.; Penzo-Mendez, A.; Riou, J.F.; Boucaut, J.C.; Shi, D.L. The C-terminal cytoplasmic Lys-thr-X-X-X-Trp motif in frizzled receptors mediates Wnt/beta-catenin signalling. EMBO J. 2000, 19, 4944-4954. [CrossRef]

16. Cong, F.; Schweizer, L.; Varmus, H. Wnt signals across the plasma membrane to activate the beta-catenin pathway by forming oligomers containing its receptors, Frizzled and LRP. Development 2004, 131, 5103-5115. [CrossRef]

17. Cliffe, A.; Hamada, F.; Bienz, M. A role of Dishevelled in relocating Axin to the plasma membrane during wingless signaling. Curr. Biol. 2003, 13, 960-966. [CrossRef]

18. Salic, A.; Lee, E.; Mayer, L.; Kirschner, M.W. Control of beta-catenin stability: Reconstitution of the cytoplasmic steps of the wnt pathway in Xenopus egg extracts. Mol. Cell 2000, 5, 523-532. [CrossRef]

19. Grumolato, L.; Liu, G.; Mong, P.; Mudbhary, R.; Biswas, R.; Arroyave, R.; Vijayakumar, S.; Economides, A.N.; Aaronson, S.A. Canonical and noncanonical Wnts use a common mechanism to activate completely unrelated coreceptors. Genes Dev. 2010, 24, 2517-2530. [CrossRef] 
20. Kazanskaya, O.; Glinka, A.; del Barco Barrantes, I.; Stannek, P.; Niehrs, C.; Wu, W. R-Spondin2 is a secreted activator of Wnt/beta-catenin signaling and is required for Xenopus myogenesis. Dev. Cell 2004, 7, 525-534. [CrossRef]

21. Kim, K.A.; Kakitani, M.; Zhao, J.; Oshima, T.; Tang, T.; Binnerts, M.; Liu, Y.; Boyle, B.; Park, E.; Emtage, P.; et al. Mitogenic influence of human R-spondin1 on the intestinal epithelium. Science 2005, 309, 1256-1259. [CrossRef]

22. Lebensohn, A.M.; Rohatgi, R. R-spondins can potentiate WNT signaling without LGRs. Elife $2018,7$. [CrossRef] [PubMed]

23. Glinka, A.; Dolde, C.; Kirsch, N.; Huang, Y.L.; Kazanskaya, O.; Ingelfinger, D.; Boutros, M.; Cruciat, C.M.; Niehrs, C. LGR4 and LGR5 are R-spondin receptors mediating Wnt/beta-catenin and Wnt/PCP signalling. EMBO Rep. 2011, 12, 1055-1061. [CrossRef] [PubMed]

24. Carmon, K.S.; Gong, X.; Lin, Q.; Thomas, A.; Liu, Q. R-spondins function as ligands of the orphan receptors LGR4 and LGR5 to regulate Wnt/beta-catenin signaling. Proc. Natl. Acad. Sci. USA 2011, 108, 11452-11457. [CrossRef] [PubMed]

25. Dubey, R.; van Kerkhof, P.; Jordens, I.; Malinauskas, T.; Pusapati, G.V.; McKenna, J.K.; Li, D.; Carette, J.E.; Ho, M.; Siebold, C.; et al. R-spondins engage heparan sulfate proteoglycans to potentiate WNT signaling. Elife 2020, 9. [CrossRef] [PubMed]

26. Park, S.; Cui, J.; Yu, W.; Wu, L.; Carmon, K.S.; Liu, Q.J. Differential activities and mechanisms of the four R-spondins in potentiating Wnt/beta-catenin signaling. J. Biol. Chem. 2018, 293, 9759-9769. [CrossRef] [PubMed]

27. Szenker-Ravi, E.; Altunoglu, U.; Leushacke, M.; Bosso-Lefevre, C.; Khatoo, M.; Thi Tran, H.; Naert, T.; Noelanders, R.; Hajamohideen, A.; Beneteau, C.; et al. RSPO2 inhibition of RNF43 and ZNRF3 governs limb development independently of LGR4/5/6. Nature 2018, 557, 564-569. [CrossRef]

28. Kim, K.A.; Wagle, M.; Tran, K.; Zhan, X.; Dixon, M.A.; Liu, S.; Gros, D.; Korver, W.; Yonkovich, S.; Tomasevic, N.; et al. R-Spondin family members regulate the Wnt pathway by a common mechanism. Mol. Biol. Cell 2008, 19, 2588-2596. [CrossRef]

29. Yan, K.S.; Janda, C.Y.; Chang, J.; Zheng, G.X.Y.; Larkin, K.A.; Luca, V.C.; Chia, L.A.; Mah, A.T.; Han, A.; Terry, J.M.; et al. Non-equivalence of Wnt and R-spondin ligands during Lgr5(+) intestinal stem-cell self-renewal. Nature 2017, 545, 238-242. [CrossRef]

30. Amit, S.; Hatzubai, A.; Birman, Y.; Andersen, J.S.; Ben-Shushan, E.; Mann, M.; Ben-Neriah, Y.; Alkalay, I. Axin-mediated CKI phosphorylation of beta-catenin at Ser 45: A molecular switch for the Wnt pathway. Genes Dev. 2002, 16, 1066-1076. [CrossRef]

31. Munemitsu, S.; Albert, I.; Souza, B.; Rubinfeld, B.; Polakis, P. Regulation of intracellular beta-catenin levels by the adenomatous polyposis coli (APC) tumor-suppressor protein. Proc. Natl. Acad. Sci. USA 1995, 92, 3046-3050. [CrossRef] [PubMed]

32. Hagen, T.; Di Daniel, E.; Culbert, A.A.; Reith, A.D. Expression and characterization of GSK-3 mutants and their effect on beta-catenin phosphorylation in intact cells. J. Biol. Chem. 2002, 277, 23330-23335. [CrossRef] [PubMed]

33. Hart, M.J.; de los Santos, R.; Albert, I.N.; Rubinfeld, B.; Polakis, P. Downregulation of beta-catenin by human Axin and its association with the APC tumor suppressor, beta-catenin and GSK3 beta. Curr. Biol. 1998, 8, 573-581. [CrossRef]

34. Liu, C.; Li, Y.; Semenov, M.; Han, C.; Baeg, G.H.; Tan, Y.; Zhang, Z.; Lin, X.; He, X. Control of beta-catenin phosphorylation/degradation by a dual-kinase mechanism. Cell 2002, 108, 837-847. [CrossRef]

35. Su, Y.; Fu, C.; Ishikawa, S.; Stella, A.; Kojima, M.; Shitoh, K.; Schreiber, E.M.; Day, B.W.; Liu, B. APC is essential for targeting phosphorylated beta-catenin to the SCFbeta-TrCP ubiquitin ligase. Mol. Cell 2008, 32, 652-661. [CrossRef] [PubMed]

36. Rubinfeld, B.; Tice, D.A.; Polakis, P. Axin-dependent phosphorylation of the adenomatous polyposis coli protein mediated by casein kinase 1epsilon. J. Biol. Chem. 2001, 276, 39037-39045. [CrossRef]

37. Xing, Y.; Clements, W.K.; Kimelman, D.; Xu, W. Crystal structure of a beta-catenin/axin complex suggests a mechanism for the beta-catenin destruction complex. Genes Dev. 2003, 17, 2753-2764. [CrossRef]

38. Orford, K.; Crockett, C.; Jensen, J.P.; Weissman, A.M.; Byers, S.W. Serine phosphorylation-regulated ubiquitination and degradation of beta-catenin. J. Biol. Chem. 1997, 272, 24735-24738. [CrossRef] 
39. Hart, M.; Concordet, J.P.; Lassot, I.; Albert, I.; del los Santos, R.; Durand, H.; Perret, C.; Rubinfeld, B.; Margottin, F.; Benarous, R.; et al. The F-box protein beta-TrCP associates with phosphorylated beta-catenin and regulates its activity in the cell. Curr. Biol. 1999, 9, 207-210. [CrossRef]

40. Saito-Diaz, K.; Benchabane, H.; Tiwari, A.; Tian, A.; Li, B.; Thompson, J.J.; Hyde, A.S.; Sawyer, L.M.; Jodoin, J.N.; Santos, E.; et al. APC inhibits ligand-independent Wnt signaling by the clathrin endocytic pathway. Dev. Cell 2018, 44,566-581. [CrossRef]

41. Cabel, C.R.; Alizadeh, E.; Robbins, D.J.; Ahmed, Y.; Lee, E.; Thorne, C.A. Single-Cell analyses confirm the critical role of LRP6 for Wnt signaling in APC-deficient cells. Dev. Cell 2019, 49, 827-828. [CrossRef] [PubMed]

42. Yang, E.; Tacchelly-Benites, O.; Wang, Z.; Randall, M.P.; Tian, A.; Benchabane, H.; Freemantle, S.; Pikielny, C.; Tolwinski, N.S.; Lee, E.; et al. Wnt pathway activation by ADP-ribosylation. Nat. Commun. 2016, 7, 11430. [CrossRef] [PubMed]

43. Tolwinski, N.S.; Wehrli, M.; Rives, A.; Erdeniz, N.; DiNardo, S.; Wieschaus, E. Wg/Wnt signal can be transmitted through arrow/LRP5,6 and Axin independently of Zw3/Gsk3beta activity. Dev. Cell 2003, 4, 407-418. [CrossRef]

44. Stamos, J.L.; Weis, W.I. The beta-catenin destruction complex. Cold Spring Harb. Perspect. Biol. 2013, 5, a007898. [CrossRef] [PubMed]

45. Kimelman, D.; Xu, W. beta-catenin destruction complex: Insights and questions from a structural perspective. Oncogene 2006, 25, 7482-7491. [CrossRef]

46. Cselenyi, C.S.; Jernigan, K.K.; Tahinci, E.; Thorne, C.A.; Lee, L.A.; Lee, E. LRP6 transduces a canonical Wnt signal independently of Axin degradation by inhibiting GSK3's phosphorylation of beta-catenin. Proc. Natl. Acad. Sci. USA 2008, 105, 8032-8037. [CrossRef] [PubMed]

47. Hernandez, A.R.; Klein, A.M.; Kirschner, M.W. Kinetic responses of beta-catenin specify the sites of Wnt control. Science 2012, 338, 1337-1340. [CrossRef] [PubMed]

48. Lee, E.; Salic, A.; Kruger, R.; Heinrich, R.; Kirschner, M.W. The roles of APC and axin derived from experimental and theoretical analysis of the Wnt pathway. PLoS Biol. 2003, E10. [CrossRef] [PubMed]

49. Huang, S.M.; Mishina, Y.M.; Liu, S.; Cheung, A.; Stegmeier, F.; Michaud, G.A.; Charlat, O.; Wiellette, E.; Zhang, Y.; Wiessner, S.; et al. Tankyrase inhibition stabilizes axin and antagonizes Wnt signalling. Nature 2009, 461, 614-620. [CrossRef]

50. Ji, L.; Jiang, B.; Jiang, X.; Charlat, O.; Chen, A.; Mickanin, C.; Bauer, A.; Xu, W.; Yan, X.; Cong, F. The SIAH E3 ubiquitin ligases promote $\mathrm{Wnt} /$ beta-catenin signaling through mediating Wnt-induced axin degradation. Genes Dev. 2017, 31, 904-915. [CrossRef]

51. Daniels, D.L.; Weis, W.I. Beta-catenin directly displaces Groucho/TLE repressors from Tcf/Lef in Wnt-mediated transcription activation. Nat. Struct. Mol. Biol. 2005, 12, 364-371. [CrossRef] [PubMed]

52. Hanson, A.J.; Wallace, H.A.; Freeman, T.J.; Beauchamp, R.D.; Lee, L.A.; Lee, E. XIAP monoubiquitylates Groucho/TLE to promote canonical Wnt signaling. Mol. Cell 2012, 45, 619-628. [CrossRef] [PubMed]

53. Flack, J.E.; Mieszczanek, J.; Novcic, N.; Bienz, M. Wnt-dependent inactivation of the groucho/TLE co-repressor by the HECT E3 ubiquitin ligase Hyd/UBR5. Mol. Cell 2017, 67, 181-193.E5. [CrossRef] [PubMed]

54. Benchabane, H.; Xin, N.; Tian, A.; Hafler, B.P.; Nguyen, K.; Ahmed, A.; Ahmed, Y. Jerky/Earthbound facilitates cell-specific Wnt/Wingless signalling by modulating beta-catenin-TCF activity. EMBO J. 2011, 30, 1444-1458. [CrossRef] [PubMed]

55. Kramps, T.; Peter, O.; Brunner, E.; Nellen, D.; Froesch, B.; Chatterjee, S.; Murone, M.; Zullig, S.; Basler, K. Wnt/wingless signaling requires BCL9/legless-mediated recruitment of pygopus to the nuclear beta-catenin-TCF complex. Cell 2002, 109, 47-60. [CrossRef]

56. Fuste, N.P.; Fernandez-Hernandez, R.; Cemeli, T.; Mirantes, C.; Pedraza, N.; Rafel, M.; Torres-Rosell, J.; Colomina, N.; Ferrezuelo, F.; Dolcet, X.; et al. Cytoplasmic cyclin D1 regulates cell invasion and metastasis through the phosphorylation of paxillin. Nat. Commun. 2016, 7. [CrossRef]

57. Wong, C.; Chen, C.; Wu, Q.; Liu, Y.; Zheng, P. A critical role for the regulated wnt-myc pathway in naive T cell survival. J. Immunol. 2015, 194, 158-167. [CrossRef]

58. Ou, L.; Fang, L.; Tang, H.; Qiao, H.; Zhang, X.; Wang, Z. Dickkopf Wnt signaling pathway inhibitor 1 regulates the differentiation of mouse embryonic stem cells in vitro and in vivo. Mol. Med. Rep. 2016, 13, 720-730. [CrossRef] 
59. Nusse, R.; Varmus, H.E. Many tumors induced by the mouse mammary tumor virus contain a provirus integrated in the same region of the host genome. Cell 1982, 31, 99-109. [CrossRef]

60. Tsukamoto, A.S.; Grosschedl, R.; Guzman, R.C.; Parslow, T.; Varmus, H.E. Expression of the int-1 gene in transgenic mice is associated with mammary gland hyperplasia and adenocarcinomas in male and female mice. Cell 1988, 55, 619-625. [CrossRef]

61. Polakis, P. Wnt signaling in cancer. Cold Spring Harb. Perspect. Biol. 2012. [CrossRef] [PubMed]

62. Zhan, T.; Rindtorff, N.; Boutros, M. Wnt signaling in cancer. Oncogene 2017, 36, 1461-1473. [CrossRef] [PubMed]

63. Groden, J.; Thliveris, A.; Samowitz, W.; Carlson, M.; Gelbert, L.; Albertsen, H.; Joslyn, G.; Stevens, J.; Spirio, L.; Robertson, M.; et al. Identification and characterization of the familial adenomatous polyposis coli gene. Cell 1991, 66, 589-600. [CrossRef]

64. Nishisho, I.; Nakamura, Y.; Miyoshi, Y.; Miki, Y.; Ando, H.; Horii, A.; Koyama, K.; Utsunomiya, J.; Baba, S.; Hedge, P. Mutations of chromosome 5q21 genes in FAP and colorectal cancer patients. Science 1991, 253, 665-669. [CrossRef] [PubMed]

65. Miyoshi, Y.; Ando, H.; Nagase, H.; Nishisho, I.; Horii, A.; Miki, Y.; Mori, T.; Utsunomiya, J.; Baba, S.; Petersen, G.; et al. Germ-line mutations of the APC gene in 53 familial adenomatous polyposis patients. Proc. Natl. Acad. Sci. USA 1992, 89, 4452-4456. [CrossRef] [PubMed]

66. Miyoshi, Y.; Nagase, H.; Ando, H.; Horii, A.; Ichii, S.; Nakatsuru, S.; Aoki, T.; Miki, Y.; Mori, T.; Nakamura, Y. Somatic mutations of the APC gene in colorectal tumors: Mutation cluster region in the APC gene. Hum. Mol. Genet. 1992, 1, 229-233. [CrossRef] [PubMed]

67. Powell, S.M.; Zilz, N.; Beazer-Barclay, Y.; Bryan, T.M.; Hamilton, S.R.; Thibodeau, S.N.; Vogelstein, B.; Kinzler, K.W. APC mutations occur early during colorectal tumorigenesis. Nature 1992, 359, 235-237. [CrossRef]

68. Su, L.K.; Vogelstein, B.; Kinzler, K.W. Association of the APC tumor suppressor protein with catenins. Science 1993, 262, 1734-1737. [CrossRef]

69. Korinek, V.; Barker, N.; Morin, P.J.; van Wichen, D.; de Weger, R.; Kinzler, K.W.; Vogelstein, B.; Clevers, H. Constitutive transcriptional activation by a beta-catenin-Tcf complex in APC-/- colon carcinoma. Science 1997, 275, 1784-1787. [CrossRef]

70. Clements, W.M.; Lowy, A.M.; Groden, J. Adenomatous polyposis coli/beta-catenin interaction and downstream targets: Altered gene expression in gastrointestinal tumors. Clin. Colorectal Cancer 2003, 3, 113-120. [CrossRef]

71. Kurahashi, H.; Takami, K.; Oue, T.; Kusafuka, T.; Okada, A.; Tawa, A.; Okada, S.; Nishisho, I. Biallelic inactivation of the APC gene in hepatoblastoma. Cancer Res. 1995, 55, 5007-5011. [PubMed]

72. Csepregi, A.; Rocken, C.; Hoffmann, J.; Gu, P.; Saliger, S.; Muller, O.; Schneider-Stock, R.; Kutzner, N.; Roessner, A.; Malfertheiner, P.; et al. APC promoter methylation and protein expression in hepatocellular carcinoma. J. Cancer Res. Clin. Oncol. 2008, 134, 579-589. [CrossRef] [PubMed]

73. Katoh, H.; Shibata, T.; Kokubu, A.; Ojima, H.; Kosuge, T.; Kanai, Y.; Hirohashi, S. Genetic inactivation of the APC gene contributes to the malignant progression of sporadic hepatocellular carcinoma: A case report. Genes Chromosomes Cancer 2006, 45, 1050-1057. [CrossRef] [PubMed]

74. Picco, G.; Petti, C.; Centonze, A.; Torchiaro, E.; Crisafulli, G.; Novara, L.; Acquaviva, A.; Bardelli, A.; Medico, E. Loss of AXIN1 drives acquired resistance to WNT pathway blockade in colorectal cancer cells carrying RSPO3 fusions. EMBO Mol. Med. 2017, 9, 293-303. [CrossRef]

75. Wright, K.; Wilson, P.; Morland, S.; Campbell, I.; Walsh, M.; Hurst, T.; Ward, B.; Cummings, M.; Chenevix-Trench, $\mathrm{G}$. beta-catenin mutation and expression analysis in ovarian cancer: Exon 3 mutations and nuclear translocation in 16\% of endometrioid tumours. Int, J. Cancer 1999, 82, 625-629. [CrossRef]

76. Samowitz, W.S.; Powers, M.D.; Spirio, L.N.; Nollet, F.; van Roy, F.; Slattery, M.L. Beta-catenin mutations are more frequent in small colorectal adenomas than in larger adenomas and invasive carcinomas. Cancer Res. 1999, 59, 1442-1444.

77. Lin, S.Y.; Xia, W.; Wang, J.C.; Kwong, K.Y.; Spohn, B.; Wen, Y.; Pestell, R.G.; Hung, M.C. Beta-catenin, a novel prognostic marker for breast cancer: Its roles in cyclin D1 expression and cancer progression. Proc. Natl. Acad. Sci. USA 2000, 97, 4262-4266. [CrossRef] 
78. Reifenberger, J.; Knobbe, C.B.; Wolter, M.; Blaschke, B.; Schulte, K.W.; Pietsch, T.; Ruzicka, T.; Reifenberger, G. Molecular genetic analysis of malignant melanomas for aberrations of the Wnt signaling pathway genes CTNNB1, APC, ICAT and BTRC. Int. J. Cancer 2002, 100, 549-556. [CrossRef]

79. Duval, A.; Gayet, J.; Zhou, X.P.; Iacopetta, B.; Thomas, G.; Hamelin, R. Frequent frameshift mutations of the TCF-4 gene in colorectal cancers with microsatellite instability. Cancer Res. 1999, 59, 4213-4215.

80. Cuilliere-Dartigues, P.; El-Bchiri, J.; Krimi, A.; Buhard, O.; Fontanges, P.; Flejou, J.F.; Hamelin, R.; Duval, A. TCF-4 isoforms absent in TCF-4 mutated MSI-H colorectal cancer cells colocalize with nuclear CtBP and repress TCF-4-mediated transcription. Oncogene 2006, 25, 4441-4448. [CrossRef]

81. Bond, C.E.; McKeone, D.M.; Kalimutho, M.; Bettington, M.L.; Pearson, S.A.; Dumenil, T.D.; Wockner, L.F.; Burge, M.; Leggett, B.A.; Whitehall, V.L. RNF43 and ZNRF3 are commonly altered in serrated pathway colorectal tumorigenesis. Oncotarget 2016, 7, 70589-70600. [CrossRef] [PubMed]

82. Eto, T.; Miyake, K.; Nosho, K.; Ohmuraya, M.; Imamura, Y.; Arima, K.; Kanno, S.; Fu, L.; Kiyozumi, Y.; Izumi, D.; et al. Impact of loss-of-function mutations at the RNF43 locus on colorectal cancer development and progression. J. Pathol 2018, 245, 445-455. [CrossRef] [PubMed]

83. Giannakis, M.; Hodis, E.; Jasmine Mu, X.; Yamauchi, M.; Rosenbluh, J.; Cibulskis, K.; Saksena, G.; Lawrence, M.S.; Qian, Z.R.; Nishihara, R.; et al. RNF43 is frequently mutated in colorectal and endometrial cancers. Nat. Genet. 2014, 46, 1264-1266. [CrossRef] [PubMed]

84. Xiang, X.J.; Liu, Y.W.; Chen, D.D.; Yu, S. Differential expression of Dickkopf-1 among non-small cell lung cancer cells. Mol. Med. Rep. 2015, 12, 1935-1940. [CrossRef] [PubMed]

85. Sinnberg, T.; Menzel, M.; Kaesler, S.; Biedermann, T.; Sauer, B.; Nahnsen, S.; Schwarz, M.; Garbe, C.; Schittek, B. Suppression of casein kinase 1alpha in melanoma cells induces a switch in beta-catenin signaling to promote metastasis. Cancer Res. 2010, 70, 6999-7009. [CrossRef]

86. Nagahata, T.; Shimada, T.; Harada, A.; Nagai, H.; Onda, M.; Yokoyama, S.; Shiba, T.; Jin, E.; Kawanami, O.; Emi, M. Amplification, up-regulation and over-expression of DVL-1, the human counterpart of the Drosophila disheveled gene, in primary breast cancers. Cancer Sci 2003, 94, 515-518. [CrossRef]

87. Wils, L.J.; Bijlsma, M.F. Epigenetic regulation of the Hedgehog and Wnt pathways in cancer. Crit. Rev. Oncol. Hematol. 2018, 121, 23-44. [CrossRef]

88. Nagel, R.; le Sage, C.; Diosdado, B.; van der Waal, M.; Oude Vrielink, J.A.; Bolijn, A.; Meijer, G.A.; Agami, R. Regulation of the adenomatous polyposis coli gene by the miR-135 family in colorectal cancer. Cancer Res. 2008, 68, 5795-5802. [CrossRef]

89. Nguyen, T.M.; Kabotyanski, E.B.; Dou, Y.; Reineke, L.C.; Zhang, P.; Zhang, X.H.; Malovannaya, A.; Jung, S.Y.; Mo, Q.; Roarty, K.P.; et al. FGFR1-activated translation of Wnt pathway components with structured 5' UTRs is vulnerable to inhibition of EIF4A-dependent translation initiation. Cancer Res. 2018, 78, 4229-4240. [CrossRef]

90. Liang, W.C.; Wong, C.W.; Liang, P.P.; Shi, M.; Cao, Y.; Rao, S.T.; Tsui, S.K.; Waye, M.M.; Zhang, Q.; Fu, W.M.; et al. Translation of the circular RNA circbeta-catenin promotes liver cancer cell growth through activation of the Wnt pathway. Genome Biol. 2019, 20. [CrossRef]

91. Han, B.; Yan, S.; Wei, S.; Xiang, J.; Liu, K.; Chen, Z.; Bai, R.; Sheng, J.; Xu, Z.; Gao, X. YTHDF1-mediated translation amplifies Wnt-driven intestinal stemness. EMBO Rep. 2020, 21, e49229. [CrossRef] [PubMed]

92. Jung, H.; Kim, B.G.; Han, W.H.; Lee, J.H.; Cho, J.Y.; Park, W.S.; Maurice, M.M.; Han, J.K.; Lee, M.J.; Finley, D.; et al. Deubiquitination of Dishevelled by Usp14 is required for Wnt signaling. Oncogenesis 2013, 2, e64. [CrossRef] [PubMed]

93. Gao, C.; Cao, W.; Bao, L.; Zuo, W.; Xie, G.; Cai, T.; Fu, W.; Zhang, J.; Wu, W.; Zhang, X.; et al. Autophagy negatively regulates Wnt signalling by promoting dishevelled degradation. Nat. Cell Biol. 2010, 12, 781-790. [CrossRef] [PubMed]

94. Liu, L.; Zhang, Y.; Wong, C.C.; Zhang, J.; Dong, Y.; Li, X.; Kang, W.; Chan, F.K.L.; Sung, J.J.Y.; Yu, J. RNF6 promotes colorectal cancer by activating the Wnt/beta-catenin pathway via ubiquitination of TLE3. Cancer Res. 2018, 78, 1958-1971. [CrossRef] [PubMed]

95. Thorne, C.A.; Hanson, A.J.; Schneider, J.; Tahinci, E.; Orton, D.; Cselenyi, C.S.; Jernigan, K.K.; Meyers, K.C.; Hang, B.I.; Waterson, A.G.; et al. Small-molecule inhibition of Wnt signaling through activation of casein kinase 1alpha. Nat. Chem. Biol. 2010, 6, 829-836. [CrossRef] 
96. Li, B.; Flaveny, C.A.; Giambelli, C.; Fei, D.L.; Han, L.; Hang, B.I.; Bai, F.; Pei, X.H.; Nose, V.; Burlingame, O.; et al. Repurposing the FDA-approved pinworm drug pyrvinium as a novel chemotherapeutic agent for intestinal polyposis. PLoS ONE 2014, 9, e101969. [CrossRef]

97. Li, B.; Orton, D.; Neitzel, L.R.; Astudillo, L.; Shen, C.; Long, J.; Chen, X.; Kirkbride, K.C.; Doundoulakis, T.; Guerra, M.L.; et al. Differential abundance of CK1alpha provides selectivity for pharmacological CK1alpha activators to target Wnt-dependent tumors. Sci. Signal. 2017, 10. [CrossRef]

98. Xu, W.; Lacerda, L.; Debeb, B.G.; Atkinson, R.L.; Solley, T.N.; Li, L.; Orton, D.; McMurray, J.S.; Hang, B.I.; Lee, E.; et al. The antihelmintic drug pyrvinium pamoate targets aggressive breast cancer. PLoS ONE 2013, 8, e71508. [CrossRef]

99. Zhang, C.; Zhang, Z.; Zhang, S.; Wang, W.; Hu, P. Targeting of Wnt/beta-catenin by anthelmintic drug pyrvinium enhances sensitivity of ovarian cancer cells to chemotherapy. Med. Sci Monit. 2017, 23, 266-275. [CrossRef]

100. Zheng, L.; Liu, Y.; Pan, J. Inhibitory effect of pyrvinium pamoate on uveal melanoma cells involves blocking of Wnt/beta-catenin pathway. Acta Biochim. Biophys. Sin. (Shanghai) 2017, 49, 890-898. [CrossRef]

101. Cui, L.; Zhao, J.; Liu, J. Pyrvinium sensitizes clear cell renal cell carcinoma response to chemotherapy via casein kinase 1alpha-dependent inhibition of Wnt/beta-catenin. Am. J. Med. Sci. 2018, 355, 274-280. [CrossRef] [PubMed]

102. Matsumura, S.; Takeda, M. Phosphoprotein kinases from rat liver cytosol. Biochim. Biophys. Acta 1972, 289, 237-241. [CrossRef]

103. Hathaway, G.M.; Traugh, J.A. Cyclic nucleotide-independent protein kinases from rabbit reticulocytes. Purification of casein kinases. J. Biol. Chem. 1979, 254, 762-768. [PubMed]

104. Knippschild, U.; Gocht, A.; Wolff, S.; Huber, N.; Lohler, J.; Stoter, M. The casein kinase 1 family: Participation in multiple cellular processes in eukaryotes. Cell Signal. 2005, 17, 675-689. [CrossRef] [PubMed]

105. Flotow, H.; Graves, P.R.; Wang, A.Q.; Fiol, C.J.; Roeske, R.W.; Roach, P.J. Phosphate groups as substrate determinants for casein kinase I action. J. Biol. Chem. 1990, 265, 14264-14269.

106. Xu, Y.; Lee, S.H.; Kim, H.S.; Kim, N.H.; Piao, S.; Park, S.H.; Jung, Y.S.; Yook, J.I.; Park, B.J.; Ha, N.C. Role of CK1 in GSK3beta-mediated phosphorylation and degradation of snail. Oncogene 2010, 29, 3124-3133. [CrossRef]

107. Marin, O.; Bustos, V.H.; Cesaro, L.; Meggio, F.; Pagano, M.A.; Antonelli, M.; Allende, C.C.; Pinna, L.A.; Allende, J.E. A noncanonical sequence phosphorylated by casein kinase 1 in beta-catenin may play a role in casein kinase 1 targeting of important signaling proteins. Proc. Natl. Acad. Sci. USA 2003, 100, 10193-10200. [CrossRef]

108. Cruciat, C.M. Casein kinase 1 and Wnt/beta-catenin signaling. Curr. Opin. Cell. Biol. 2014, 31, 46-55. [CrossRef]

109. Peters, J.M.; McKay, R.M.; McKay, J.P.; Graff, J.M. Casein kinase I transduces Wnt signals. Nature 1999, 401, 345-350. [CrossRef]

110. Lee, E.; Salic, A.; Kirschner, M.W. Physiological regulation of [beta]-catenin stability by Tcf3 and CK1epsilon. J. Cell Biol. 2001, 154, 983-993. [CrossRef]

111. Davidson, G.; Wu, W.; Shen, J.; Bilic, J.; Fenger, U.; Stannek, P.; Glinka, A.; Niehrs, C. Casein kinase 1 gamma couples Wnt receptor activation to cytoplasmic signal transduction. Nature 2005, 438, 867-872. [CrossRef] [PubMed]

112. Lebensohn, A.M.; Dubey, R.; Neitzel, L.R.; Tacchelly-Benites, O.; Yang, E.; Marceau, C.D.; Davis, E.M.; Patel, B.B.; Bahrami-Nejad, Z.; Travaglini, K.J.; et al. Comparative genetic screens in human cells reveal new regulatory mechanisms in WNT signaling. Elife 2016, 5. [CrossRef]

113. Rosenbluh, J.; Nijhawan, D.; Cox, A.G.; Li, X.; Neal, J.T.; Schafer, E.J.; Zack, T.I.; Wang, X.; Tsherniak, A.; Schinzel, A.C.; et al. beta-Catenin-driven cancers require a YAP1 transcriptional complex for survival and tumorigenesis. Cell 2012, 151, 1457-1473. [CrossRef] [PubMed]

114. Yong, T.J.; Gan, Y.Y.; Toh, B.H.; Sentry, J.W. Human CKIalpha(L) and CKIalpha(S) are encoded by both 2.4and $4.2-\mathrm{kb}$ transcripts, the longer containing multiple RNA-destablising elements. Biochim. Biophys. Acta 2000, 1492, 425-433. [CrossRef]

115. Zhang, J.; Gross, S.D.; Schroeder, M.D.; Anderson, R.A. Casein kinase I alpha and alpha L: Alternative splicing-generated kinases exhibit different catalytic properties. Biochemistry 1996, 35, 16319-16327. [CrossRef] 
116. Burzio, V.; Antonelli, M.; Allende, C.C.; Allende, J.E. Biochemical and cellular characteristics of the four splice variants of protein kinase CK1alpha from zebrafish (Danio rerio). J. Cell Biochem. 2002, 86, 805-814. [CrossRef] [PubMed]

117. Fu, Z.; Chakraborti, T.; Morse, S.; Bennett, G.S.; Shaw, G. Four casein kinase I isoforms are differentially partitioned between nucleus and cytoplasm. Exp. Cell Res. 2001, 269, 275-286. [CrossRef]

118. Budini, M.; Jacob, G.; Jedlicki, A.; Perez, C.; Allende, C.C.; Allende, J.E. Autophosphorylation of carboxy-terminal residues inhibits the activity of protein kinase CK1alpha. J. Cell Biochem. 2009, 106, 399-408. [CrossRef]

119. Shen, C.; Li, B.; Astudillo, L.; Deutscher, M.P.; Cobb, M.H.; Capobianco, A.J.; Lee, E.; Robbins, D.J. The CK1alpha activator pyrvinium enhances the catalytic efficiency $(\mathrm{kcat} / \mathrm{Km})$ of CK1alpha. Biochemistry 2019, 58, 5102-5106. [CrossRef]

120. Li, L.; Ren, C.; Yang, G.; Fattah, E.A.; Goltsov, A.A.; Kim, S.M.; Lee, J.S.; Park, S.; Demayo, F.J.; Ittmann, M.M.; et al. GLIPR1 suppresses prostate cancer development through targeted oncoprotein destruction. Cancer Res. 2011, 71, 7694-7704. [CrossRef]

121. Fulcher, L.J.; Bozatzi, P.; Tachie-Menson, T.; Wu, K.Z.L.; Cummins, T.D.; Bufton, J.C.; Pinkas, D.M.; Dunbar, K.; Shrestha, S.; Wood, N.T.; et al. The DUF1669 domain of FAM83 family proteins anchor casein kinase 1 isoforms. Sci. Signal. 2018, 11. [CrossRef] [PubMed]

122. Bozatzi, P.; Dingwell, K.S.; Wu, K.Z.; Cooper, F.; Cummins, T.D.; Hutchinson, L.D.; Vogt, J.; Wood, N.T.; Macartney, T.J.; Varghese, J.; et al. PAWS1 controls Wnt signalling through association with casein kinase 1alpha. EMBO Rep. 2018, 19. [CrossRef]

123. Cruciat, C.M.; Dolde, C.; de Groot, R.E.; Ohkawara, B.; Reinhard, C.; Korswagen, H.C.; Niehrs, C. RNA helicase DDX3 is a regulatory subunit of casein kinase 1 in Wnt-beta-catenin signaling. Science 2013, 339, 1436-1441. [CrossRef]

124. Huang, Q.; Chen, L.; Schonbrunn, E.; Chen, J. MDMX inhibits casein kinase 1alpha activity and stimulates Wnt signaling. EMBO J. 2020, e104410. [CrossRef]

125. Swiatek, W.; Tsai, I.C.; Klimowski, L.; Pepler, A.; Barnette, J.; Yost, H.J.; Virshup, D.M. Regulation of casein kinase I epsilon activity by Wnt signaling. J. Biol. Chem. 2004, 279, 13011-13017. [CrossRef]

126. Xu, R.M.; Carmel, G.; Sweet, R.M.; Kuret, J.; Cheng, X. Crystal structure of casein kinase-1, a phosphate-directed protein kinase. EMBO J. 1995, 14, 1015-1023. [CrossRef]

127. Barham, W.; Frump, A.L.; Sherrill, T.P.; Garcia, C.B.; Saito-Diaz, K.; VanSaun, M.N.; Fingleton, B.; Gleaves, L.; Orton, D.; Capecchi, M.R.; et al. Targeting the Wnt pathway in synovial sarcoma models. Cancer Discov. 2013, 3, 1286-1301. [CrossRef]

128. Smith, T.C.; Kinkel, A.W.; Gryczko, C.M.; Goulet, J.R. Absorption of pyrvinium pamoate. Clin. Pharmacol Ther. 1976, 19, 802-806. [CrossRef]

129. Rodriguez-Blanco, J.; Li, B.; Long, J.; Shen, C.; Yang, F.; Orton, D.; Collins, S.; Kasahara, N.; Ayad, N.G.; McCrea, H.J.; et al. A CK1alpha activator penetrates the brain and shows efficacy against drug-resistant metastatic medulloblastoma. Clin. Cancer Res. 2019, 25, 1379-1388. [CrossRef]

130. Madan, B.; McDonald, M.J.; Foxa, G.E.; Diegel, C.R.; Williams, B.O.; Virshup, D.M. Bone loss from Wnt inhibition mitigated by concurrent alendronate therapy. Bone Res. 2018, 6, 17. [CrossRef]

131. Funck-Brentano, T.; Nilsson, K.H.; Brommage, R.; Henning, P.; Lerner, U.H.; Koskela, A.; Tuukkanen, J.; Cohen-Solal, M.; Moverare-Skrtic, S.; Ohlsson, C. Porcupine inhibitors impair trabecular and cortical bone mass and strength in mice. J. Endocrinol. 2018, 238, 13-23. [CrossRef] [PubMed]

132. Tan, D.; Ng, M.; Subbiah, V.; Messersmith, W.; Teneggi, V.; Diermayr, V.; Ethirajulu, K.; Yeo, P.; Gan, B.; Lee, L. 71 O Phase I extension study of ETC-159 an oral PORCN inhibitor administered with bone protective treatment, in patients with advanced solid tumours. Annals. Oncol. 2018, 29, mdy430-002. [CrossRef]

133. Schittek, B.; Sinnberg, T. Biological functions of casein kinase 1 isoforms and putative roles in tumorigenesis. Mol. Cancer 2014, 13, 231. [CrossRef]

134. Li, B.; Fei, D.L.; Flaveny, C.A.; Dahmane, N.; Baubet, V.; Wang, Z.; Bai, F.; Pei, X.H.; Rodriguez-Blanco, J.; Hang, B.; et al. Pyrvinium attenuates Hedgehog signaling downstream of smoothened. Cancer Res. 2014, 74, 4811-4821. [CrossRef] 
135. Cheong, J.K.; Zhang, F.; Chua, P.J.; Bay, B.H.; Thorburn, A.; Virshup, D.M. Casein kinase 1alpha-dependent feedback loop controls autophagy in RAS-driven cancers. J. Clin. Investig. 2015, 125, 1401-1418. [CrossRef]

136. Saraswati, S.; Alfaro, M.P.; Thorne, C.A.; Atkinson, J.; Lee, E.; Young, P.P. Pyrvinium, a potent small molecule Wnt inhibitor, promotes wound repair and post-MI cardiac remodeling. PLoS ONE 2010, 5, e15521. [CrossRef]

(C) 2020 by the authors. Licensee MDPI, Basel, Switzerland. This article is an open access article distributed under the terms and conditions of the Creative Commons Attribution (CC BY) license (http://creativecommons.org/licenses/by/4.0/). 